\title{
KARAKTERISTIK MORFOLOGI DAN BEBERAPA SIFAT KIMIA TANAH PADA LAHAN PERTANAMAN UBI KAYU (Manihot esculenta Crantz) DAN KEBUN CAMPURAN DI DESA ADIPURO KECAMATAN TRIMURJO, KABUPATEN LAMPUNG TENGAH
}

\section{KARAKTERISTIK MORFOLOGI DAN BEBERAPA SIFAT KIMIA TANAH PADA LAHAN PERTANAMAN UBI KAYU (Manihot esculenta Crantz) DAN KEBUN CAMPURAN DI DESA ADIPURO KECAMATAN TRIMURJO, KABUPATEN LAMPUNG TENGAH}

\author{
M. Rizki Ramandha*, Didin Wiharso, Supriatin, Abdul Kadir Salam \\ Jurusan Agroteknologi, Fakultas Pertanian, Universitas Lampung \\ J1 Sumantri Brojonegoro 1, Bandar Lampung 35145, Indonesia \\ *Email: rizkirmndha08@gmail.com
}

\begin{abstract}
Cassava (Manihot esculenta Crantz) has a good adaptability, which can grow in soil conditions that have a acidic $\mathrm{pH}$, high content of Al compounds and potentially poor physical soil properties. In the short term intensive tillage is positive for plants, but overland cultivation in the long run will have a negative impact on land productivity and degrade soil quality. Meanwhile, in mixed garden lands apply a minimum tillage system that can protect the soil from erosion resulting in erosion of the top soil layer and reduce soil evaporation so as to maintain soil moisture. This study aims to study differences in morphology and chemical properties of soil on land that has been planted with cassava and mixed gardens for 15 years in Adipuro Village, Trimurjo District, Central Lampung Regency. In its implementation, this research was conducted with a survey stage, namely location determination, data collection, and laboratory analysis. The results of this study indicate that mixed garden land has better soil morphology and chemical properties than cassava plantations.
\end{abstract}

Keywords: Cassava, chemical properties, mixed gardens, soil morphology, tillage

\begin{abstract}
ABSTRAK
Ubi kayu (Manihot esculenta Crantz) memiliki kemampuan adaptasi yang baik, yaitu dapat tumbuh pada kondisi tanah yang memiliki $\mathrm{pH}$ masam, kandungan senyawa $\mathrm{Al}$ yang tinggi dan sifat fisik tanah yang kurang baik yang sangat potensial. Dalam jangka pendek pengolahan tanah intensif bersifat positif bagi tanaman, namun pengolahan tanah secara berlebih dalam jangka panjang akan menimbulkan dampak negatif terhadap produktivitas lahan dan menurunkan kualitas tanah.Sedangkan, pada lahan kebun campuran menerapkan sistem olah tanah minimum yang dapat menjaga tanah dari bahaya erosi yang mengakibatkan terjadinya pengikisan lapisan top soil dan mengurangi evaporasi tanah sehingga mempertahankan kelembaban tanah. Penelitian ini bertujuan untuk mempelajari perbedaan morfologi dan sifat kimia tanah pada lahan yang telah ditanami ubi kayu dan kebun campuran selama 15 tahun di Desa Adipuro, Kecamatan Trimurjo, Kabupaten Lampung Tengah. Dalam pelaksanaanya, penelitian ini dilakukan dengan tahapan survei yaitu penentuan lokasi, pengumpulan data, dan
\end{abstract}


analisis laboratorium. Hasil penelitian ini menunjukkan pada lahan kebun campuran memiliki morfologi tanah dan sifat kimia yang lebih baik dibanding pertanaman ubi kayu.

Kata kunci: Kebun campuran, morfologi tanah, olah tanah, sifat kimia, ubi kayu.

\section{PENDAHULUAN}

Ubi kayu merupakan komoditas tanaman pangan yang memiliki kandungan karbohidrat tinggi, protein, vitamin, zat besi, kalsium, dan fosfor pada umbinya (Akinfala dkk., 2002 dalam Caniago dkk., 2014).Ubi kayu dapat dijadikan sebagai pangan alternatif pengganti beras dalam mengatasi menurunnya ketahanan pangan di Indonesia. Selain itu, ubi kayu memiliki keunggulan yang tidak dimiliki tanaman pangan lain, yaitu dapat tumbuh di lahan kering dan kurang subur serta masa panennya yang tidak diburu waktu sehingga dapat dijadikan lumbung hidup.

Penerapan sistem olah tanah intensif yang dilakukan secara terus menerus dan tidak diimbangi dengan kegiatan konservasi dapat mempercepat terjadinya perombakan bahan organik dan memicu terjadinya erosi yang merupakan penyebab degradasi tanah (Utomo, 2012). Jika kondisi ini berlangsung dalam jangka waktu yang panjang maka degradasi tanah akan berjalan lebih cepat, sehingga dapat menurunkan kualitas tanah. Berbeda dengan pertanaman ubi kayu, prosespenanaman vegetasi tanaman tahunanpada kebun campuran dilakukan dengan pembuatan lubang tanam, disertai dengan pengolahan tanah.Penyebaran vegetasi pada kebun campuran terjadi dengan bantuan angin dan air hujan sehingga perkembangan kebun campuran berlangsung secara alami. Kebun campuran mampu berperan dalam konservasi tanah dan air. Hal ini karena keragaman vegetasi tanaman tahunan yang tinggi menciptakan kanopi yang rapat sehingga permukaan tanah lahan kebun campuran terlindung dari paparan sinar matahari, mengurangi daya pukul air hujan dan meningkatkan daya serap air pada tanah.Selain itu, kebun campuran juga berperan dalam konservasi biologi dan iklim mikro. Berdasarkan hal tersebut, lahan kebun campuran dapat dijadikan pembanding untuk melihat perbedaan morfologi dan sifat kimia tanah karena merupakan pola penggunaan lahan yang lebih konservatif dibandingkan dengan lahan pertanaman ubi kayu.

Untuk itu, penelitian tentang morfologi dan beberapa sifat kimia tanah pada lahan pertanaman ubi kayu dan kebun campuran yang telah digunakan dalam jangka waktu selama 15 tahunakan dilakukan.

\section{BAHAN DAN METODE}

Penelitian ini dilaksanakan di lahan pertanaman ubi kayu dan kebun campuran yang telah ditanami selama 15 tahun di Desa Adipuro, Kecamatan Trimurjo, Kabupaten Lampung Tengah padabulan Februari 2018. Analisis sampel tanah dilakukan di Laboratorium Ilmu Tanah, Fakultas Pertanian, Universitas Lampung.

Luas keseluruhan lahan pertanaman ubi kayu di Desa Adi Puro adalah 5 ha sedangkan luas lahan kebun campuran adalah 5 ha. Sampel lahan ditentukan dengan melihat keadaan topografi yang relatif datar dan pola penggunaan lahan yang sesuai dengan kondisi yang telah ditentukan. Pengumpulan data pola 
penggunaan lahan dilakukan dengan wawancara langsung kepada pemilik lahan yang meliputi sejarah penggunaan lahan, teknik pengolahan tanah dan pemupukan. Penentuan lahan kebun campuran dilakukan dengan kriteria berada di sekitar lokasi ubi kayu dan memiliki topografi yang relatif sama.

Setelah itu dilakukan pengumpulan data iklim berupa data curah hujan dan suhu udara daerah penelitian. Pengumpulan data batuan induk juga dilakukan dengan melihat peta geologi daerah tempat penelitian dan memastikan lahan pertanaman ubi kayu dan kebun campuran yang akan digunakan memiliki formasi geologi yang sama sehingga keduanyamemiliki persamaan proses pedogenik dan hanya berbeda pada pola penggunaan lahannya saja. Dengan proses pedogenik yang sama dan hanya berbeda pada pola penggunaan lahan, maka morfologi dan sifat kimia tanah pada kedua lahan tersebut dapat dibandingkan.

Setelah didapatkan lahan yang sesuai dan kedua lahan tersebut dinyatakan berada pada kondisi yang relatif sama, selanjutnya dilakukan pengeboran sebanyak dua titik di lahan yang akan dibuat profil untuk mengetahui keseragaman sifat tanahnya (Mahi, 2013). Satu profil tanah dibuat pada masing-masing lahan dengan ukuran $150 \mathrm{~cm}$ x $100 \mathrm{~cm}$ x $200 \mathrm{~cm}$.

Pengumpulan data di lapang dilakukan dengan pengamatan profil tanah dan kondisi pada masing-masing lahan pertanaman ubi kayu dan kebun campuran. Deskripsi profil tanah dilakukan dengan mengamati dan mencatat morfologi tanah serta kondisi lingkungan pada formulir profil tanah (Mahi, 2013). Pengamatan morfologi tanah di lapang dilakukan berdasarkan kriteria Balai Penelitian Tanah (2004).
Penampang profil tanah yang diamati adalah penampang yang mendapat pencahayaan cukup, namun tidak terpapar sinar matahari langsung dan juga tidak ternaungi. Pengamatan dilakukan pada pagi hari, namun tidak terlalu pagi atau sore ketika sinar matahari masih lemah (Rayes, 2006). Sebelum pengamatan profil tanah, penampang tanah dibasahi hingga berada dalam kondisi lembab. Pembuatan garis batas perbedaan warna pada profil tanah dilakukan dengan mengunakan pisau pandu sehingga terlihat batas perbedaan warna lapisan-lapisan tanah. Setelah itu morfologi tanah pada masing-masing lapisan tanah pada profil tanah beserta kondisi lingkungan diamati dan dicatat pada formulir profil tanah.

Lapisan tanah diukur ketebalannya beserta batas topografi dan batas kejelasan warna lapisan tanah. Setiap lapisan diamati warna matriknya menggunakan Buku Munsell Soil Color Chart. Selain warna matrik, dilakukan pengamatan warna lain seperti warna gley, karat, dan konkresi. Pengamatan proporsi dan ukuran konkresi serta karat yang dominan dilakukan pada setiap lapisan tanah pada masingmasing profil tanah. Setelah itu dilakukan pengambilan massa tanah dan diberikan sedikit remasan untuk melihat struktur tanah. Agregat yang diamati adalah agregat yang bentuknya paling dominan. Selanjutnya dilakukan pengamatan konsistensi pada keadaan lembab dengan membasahi massa tanah menggunakan air hingga keadaan lembab dan meremas massa tanah menggunakan ibu jari dan telunjuk. Pengamatan tekstur tanah juga dilakukan dengan membasahi massa tanah dengan air hingga keadaan lembab dan memijat massa tanah menggunakan ibu jari dan telunjuk sambil 
memperhatikan rasa kasar, licin dan lekat.

Setelah itu dilakukan pengambilan sampel tanah pada setiap lapisan pada masing-masing profil tanah. Pengambilan sampel tanah dilakukan dengan mengambil sampel tanah terganggu secukupnya untuk analisis sifat kimia dan tekstur tanah di laboratorium.

Sebelum dilakukan analisis tanah, contoh tanah terganggu dikering udarakan selama 4 x 24 jam. Kemudian tanah tersebut ditumbuk dan diayak menggunakan ayakan $2 \mathrm{~mm}$. Tanah yang lolos ayakan $2 \mathrm{~mm}$ kemudian digunakan untuk analisis kimia dan tekstur tanah di laboratorium. Sifat kimia tanah yang dianalisis adalah $\mathrm{pH} \mathrm{H}_{2} \mathrm{O}$ ( $\mathrm{pH}$ meter), C-organik (Walkley and Black), kapasitas tukar kation $\left(\mathrm{NH}_{4} \mathrm{OAc} 1 \mathrm{~N}\right.$ pH 7$)$, basa-basa dapat dipertukarkan( $\mathrm{NH}_{4} \mathrm{OAc} 1 \mathrm{~N} \mathrm{pH} \mathrm{7),} \mathrm{kejenuhan} \mathrm{basa,}$ N-total ( Kjeldahl) dan P-tersedia ( Bray-1). Selain melakukan penetapan kelas tekstur menurut perasaan di lapang, tekstur tanah juga dianalisis di laboratorium dengan Metode Pipet untuk mendapatkan data proporsi pasir, debu dan liat.

Data hasil analisis sifat kimia tanah di laboratorium berupa $\mathrm{pH}_{2} \mathrm{O}, \mathrm{C}$-organik, kandungan basa-basa dapat dipertukarkan, kejenuhan basa,kapasitas tukar kation, kandungan $\mathrm{N}$-total dan P-tersediadibandingkan berdasarkan kriteria Balai Penelitian Tanah (2009). Data morfologi tanah lahan pertanaman ubi kayu dan kebun campuran berupa warna, struktur, tekstur dan konsistensi, serta sifat kimia tanahberupa $\mathrm{pH}, \mathrm{C}$-organik, KTK, kandungan bsa-basa dapat dipertukarkan, kejenuhan basa, kandungan N-total dan P-tersediadibandingkan secara kualitatif.

\section{HASIL DAN PEMBAHASAN}

\section{Letak geografis}

Penelitian dilakukan di Desa Adipuro Kecamatan Trimurjo Kabupaten Lampung Tengah pada lahan pertanaman ubi kayu dan kebun campuran.Lokasi lahan penelitian pertanamanan ubi kayu dan kebun campuran terletak pada ketinggian $61 \mathrm{~m}$ dpl. Lokasi profil tanah penelitian ubi kayu monokultur dan kebun campuran berada pada koordinat sekitar 509’24" LS dan 105¹2’18" LU.

\section{Geologi}

Secara geomorfologis, tanah di sekitar daerah penelitian merupakan enclave, yang berbeda dengan tanah disekitarnya. Tanah disekitarnya memiliki warna yang cenderung pucat/terang. Menurut peta geologi tanjung karang, wilayah di sekitar Desa Adipuro, Kecamatan Trimurjo terbentuk dari formasi Qti yaitu tufa Lampung yang berasal dari rhyolite hingga dasit. Tanah di daerah penelitian terbentuk dari batuan yang berupa metamorf hingga basa yang lebih tua dibanding tufa Lamung.

\section{Iklim}

Curah hujan minimum terjadi pada bulan September dengan rata-rata $68,0 \mathrm{~mm} /$ bulan sedangkan curah hujan maksimum terjadi pada bulan Desember dengan rata-rata 266,6 mm/bulan (Gambar 1). Data hujan harian yang sudah direkap menjadi data hujan bulanan selanjutnya dilakukan analisis.

Bulan basah (BB) dan Bulan kerting (BK) sesuai besarnya curah hujan bulanan tersebut. Dikatakan bulan basah (BB) jika jumlah curah hujan dalam bulan tersebut lebih dari $200 \mathrm{~mm} / \mathrm{bulan}$, dan dikatakan bulan kering (BK) jika jumlah curah hujan 


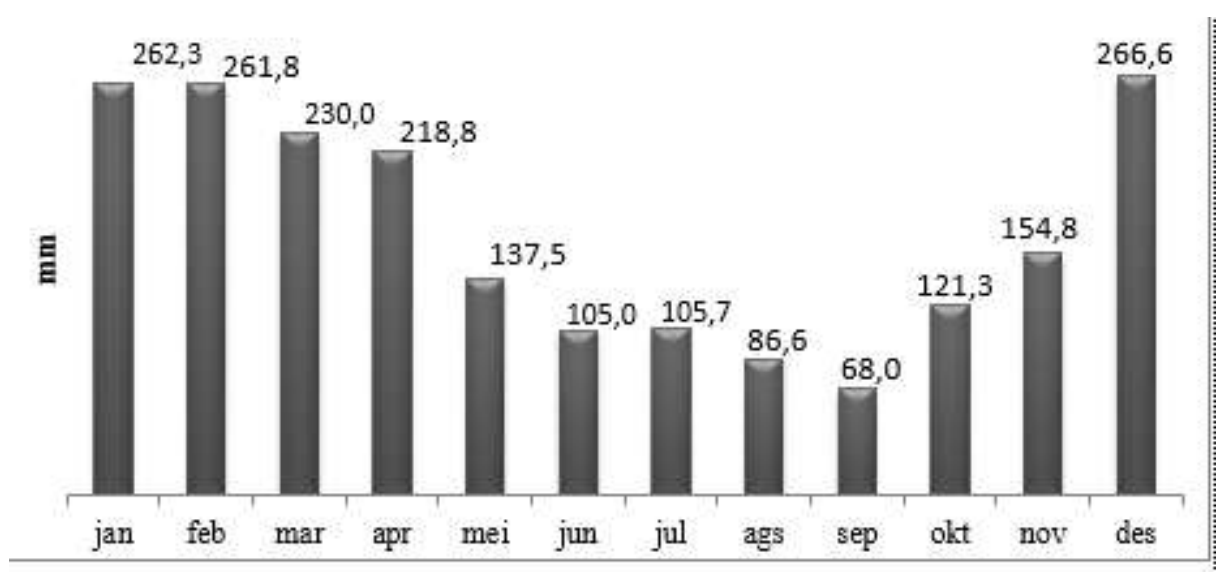

Gambar 1. Data curah hujan rata-rata bulanan 10 tahun terakhir di DesaAdipuro Kecamatan Trimurjo Kabupaten Lampung Tengah.

kurang dari $100 \mathrm{~mm} / \mathrm{bulan}$. Diantara BB dan BK terdapat bulan lembab (BL), yaitu bulan dengan jumlah curah hujan bulanan antara 100-200 mm/bulan (Lakitan,1997). Klasifikasi tipe utama pada sistem klasifikasi iklim Oldeman, dilakukan berdasarkan jumlah BB yang terjadi selama satu tahun. Wilayah dengan jumlah BB lebih dari 9 termasuk dalam tipe iklim A, wilayah dengan jumlah BB antara 7-9, termasuk dalam tipe $\mathrm{B}$, wilayah dengan jumlah BB antara 5-6 termasuk dalam tipe iklim $\mathrm{C}$, wilayah dengan jumlah BB antara 3-4 termasuk dalam tipe iklim D, dan wilayah dengan jumlah BB kurang dari3, termasuk tipe iklim E. Daerah lahan penelitian tergolong ke dalam daerah yang memiliki tipe iklim $\mathrm{C}$ karena memiiki jumlah bulan basah sebanyak 5 bulan dalam satu tahun yaitu pada bulan Januari, Februari, Maret, April, dan Desember.

\section{Penggunaan Lahan}

Lokasi penelitian di DesaAdipuro Kecamatan Trimurjo memiliki luas sekitar 5 hektar dengan vegetasi utama yaitu ubi kayu (Manihot esculenta Crantz). Lahan pertanaman ubi kayu monokultur ini mulai digunakan pada tahun 2004 sampai sekarang, menggunakan varietas ubi kayu Kasesa, dengan jarak tanam $100 \mathrm{~cm}$ x $60 \mathrm{~cm}$. Di sekitar lahan pertanaman ubi kayu terdapat vegetasi lainnya, yaitu kebun campuran yang digunakan sejak tahun 2004 sampai sekarang. Vegetasi utama pada kebun campuran yaitu mahoni (Swietenia mahagoni), karet (Hevea brasiliensis), bayur (Pterosperium javanicum Jungh), pohon duku (Lansium domesticum Corr ), kelapa (Cocos nucifera), dan jambu air (Eugenia aquea).

Pengolahan tanah pada lahan ubi kayu dilakukan secara terus menerus dengan pengolahan yang dilakukan selama 3 kali sebelum melakukan penanaman. Pada budidaya tanaman ubi kayu, kapur dolomit dan pupuk organik diberikan sebanyak 10 ton/ ha sebelum pembajakan. Pupuk anorganik yang digunakan berupa pupuk $\mathrm{KCl}$ sebanyak $100 \mathrm{~kg} / \mathrm{ha}$, pupuk Urea $100 \mathrm{~kg} / \mathrm{ha}$ dan pupuk TSP $100 \mathrm{~kg}$ /ha yang diaplikasikan 60 hari setelah tanam. Pemanenan ubi kayu sendiri dilakukan hanya 1 tahun sekali. Tanah di kebun campuran sendiri sama sekali belum pernah mengalami olah tanah, hanya sebagai kebun simpanan dan tanaman yang ada di kebun campuran tersebut tumbuh secara liar atau alami. 


\section{Morfologi}

Morfologi tanah merupakan sifat tanah yang dapat diamati langsung di lapang yang menunjukkan profil tanahke arah dalam tanah. Morfologi yang diamati dalam penelitian ini yaitu kedalaman lapisan tanah, warna, struktur dan konsistensi dan struktur tanah. Tanah pada kebun campuran bahan organiknya lebih tinggi dibandingkan tanah ubi kayu karena tanah pada ubi kayu lebih sering diolah.

\section{Warna Tanah}

Hasil pengamatan profil tanah pada pertanaman ubi kayu dan kebun campuran memiliki 5 lapisan dan warna yang berbeda. Warna tanah matriks pada lapisan I (top soil) lahan pertanaman ubi kayu yaitu 5 YR 3/ 2(reddish brown), sedangkan tanah di bawah vegetasi kebun campuran memiliki warna tanah 5 YR 3/3 (reddish brown). Lapisan (sub soil) lapisan II lahan ubi kayu memiliki warna matriks 5 YR 3/4(reddish brown), sedangkan pada lahan kebun campuran memiliki warna matriks 5 YR 4/6 (yellowish red). Warna pada lapisan III lahan ubi kayu memiliki warna 5 YR 4/4 (reddish brown), sedangkan pada lahan kebun campuran 5 YR 4/6 (yellowish red). Warna pada lapisan IV lahan ubi kayu memiliki warna 5 YR 4/4 (reddish brown),sedangkan pada lahan kebun campuran memiliki warna 5 YR 4/4 (redish brown), dan pada lapisan $\mathrm{V}$ lahan ubi kayu memiliki warna 5 YR 4/6 (yellowish red),sedangkan pada lahan kebun campuran memiliki warna 5 YR 4/4 (reddish brown). Pada saat pengamatan lahan ubi kayu terdapat karat pada lapisan II dan lapisan IV, dan memiliki konkresi pada lapisan II dan lapisan IV. Sedangkan pada lahan kebun campuran tidak terdapat karat dan konkresi.

\section{StrukturTanah}

Hasil pengamatan struktur tanah pada lapisan top soil sampai sub soil lahan ubi kayu memiliki struktur tanah angular blocky (gumpal bersudut) tetapi memiliki ukuran struktur yang berbeda.Pada lapisan pertama ubikayu dan kedua memiliki ukuran struktur halus dan tingkat perkembangan lemah, sedangkan pada lapisan ketiga dan keempat memiliki ukuran struktur sedang dan tingkat perkembangan sedang pula.Selanjutnya pada lahan kebun campuran pada lapisan top soil memiliki struktur tanah crumb (remah) dengan ukuran halus dan tingkat perkembangan sedang dan pada lapisan sub soil yaitu lapisan kedua, ketiga, keempat memiliki struktur tanah angular blocky (gumpal bersudut) dengan ukuran struktur sedang pada lapisan kedua dan tingkat perkembangan sedang, sedangkan pada lapisan ketiga dan keempat memiliki ukuran struktur tanah yang sama yaitu halus dengan tingkat perkembangan sedang pada lapisan tiga dan lemah pada lapisan keempat.

Struktur tanah lapisan pertama pada lahan kebun campuran dan ubi kayu memiliki perbedaan. Lapisan pertama lahan ubi kayu memiliki struktur tanah dalam bentuk angular blocky (gumpal bersudut) sedangkan pada lahan kebun campuran dalam bentuk crumb (remah). Perbedaan struktur tanah pada kedua lahan tersebut dikarenakan pada lahan kebun campuran memiliki bahan organik yang lebih tinggi dibandingkan lahan ubi kayu. Hasil penelitian ini sejalan dengan penelitian Pratiwi (2013) bahwa tanah yang terbuka seperti lahan ubi kayu memiliki kemantapan agregat yang lebih lemah dibandingkan dengan lahan yang tertutup. Keadaan tersebut berbanding terbalik dengan 
tingginya bahan organik pada lahan yang tertutup dan tidak dilakukannya pengolahan tanah secara intensif.

\section{Konsistensi Tanah}

Konsistensi tanah menunjukkan kekuatan daya kohesi butir - butir tanah atau daya adhesi butir - butir tanah dengan benda lain. Hal ini ditunjukkan oleh daya tanah terhadap gaya yang akan mengubah bentuk. Gaya - gaya tersebut misalnya pencangkulan dan pembajakan. Tanah yang mempunyai konsistensi baik pada umumnya mudah diolah dan tidak melekat pada alat pengolah tanah. Oleh karena tanah dapat ditemukan dalam keadaan lembab, basah, atau kering, maka penyifatan konsistensi tanah harus disesuaikan dengan keadaan tanah tersebut (Cahyono,1998).

Hasil pengamatan profil tanah menunjukkan bahwa lahan ubi kayu dan kebun campuran memiliki konsistensi relatif sama, yaitu pada lapisan I tanah dibawah vegetasi ubi kayu dan kebun campuran memiliki konsistensi gembur, pada lapisan II agak teguh, pada lapisan III agak teguh, lapisan IV teguh dan pada lapisan V teguh. Konsistensi tanah agak teguh sampai teguh memiliki arti memerlukan tekanan yang besar untuk menghancurkan tanah dan tanah sama sekali tidak mudah untuk dihancurkan dengan remasan tangan.

\section{Tekstur Tanah}

Makin kecil ukuran separate (tanah) berarti makin banyak jumlah dan makin luas permukaannya per satuan bobot tanah, yang menunjukkan makin padatnya partikel-partikel per satuan volume tanah. Hal ini berarti makin banyak ukuran pori mikro yang terbentuk, sebaliknya jika ukuran separate makin besar, berarti makin sedikit jumlah dan makin sempit luas permukaannya (Ali, 2005). Berdasarkan hasil pengamatan tekstur tanah di lapang dan analisis tekstur tanah di laboratorium diperoleh data bahwa pori-pori tanah pada lahan ubi kayu lebih banyak, sehingga liat lebih mudah masuk ke dalam pori-pori tanah pada lahan ubi kayu dibandingkan tanah pada kebun campuran, karena tanah pada ubi kayu sering diolah.

Dari hasil analisis tekstur didapatkan perbandingan fraksi pasir, debu dan liat yang dinyatakan dalam persen (\%). Debu adalah suatu fraksi berukuran 0.05-0.002 mm (Foth, 1991). Tanah yang didominasi debu akan banyak mempunyai pori-pori

Tabel 1. Persentase tekstur tanah pada lahan kebun ubi kayu dan campuran.

\begin{tabular}{ccccc}
\hline \multirow{2}{*}{ Lokasi } & \multicolumn{3}{c}{ Partikel Tanah (\%) } & Tekstur \\
\cline { 2 - 4 } & Pasir & Debu & Liat & Liat \\
KS 1 & 14.57 & 21.78 & 63.65 & Liat \\
KS 2 & 8.62 & 11.01 & 80.37 & Liat \\
KS 3 & 12.57 & 8.92 & 78.51 & Liat \\
KS 4 & 8.74 & 12.63 & 78.63 & Liat \\
KS 5 & 10.81 & 23.57 & 65.62 & Liat \\
KC 1 & 18.63 & 17.66 & 63.71 & Liat \\
KC 2 & 9.82 & 7.96 & 82.22 & Liat \\
KC 3 & 9.64 & 8.21 & 82.15 & Liat \\
KC 4 & 8.77 & 8.92 & 82.31 & Liat \\
KC 5 & 10.79 & 12.39 & 76.82 & \\
\hline
\end{tabular}


meso (sedang), sedangkan tanah yang didominasi liat akan banyak mempunyai pori- pori mikro (kecil). Liat merupakan suatu fraksi berukuran $<0,002 \mathrm{~mm}$. Pasir merupakan suatu fraksi berukuran 2.0-0.05 mm dan berdasarkan sistem USDA, dibedakan pasir yang sangat halus, halus, sedang, kasar dan sangat kasar. Hasil analisis menunjukkan bahwa pada pertanaman ubi kayu dan kebun campuran memiliki tekstur tanah liat (Tabel 1).

Tabel 1 menunjukkan bahwa tekstur tanah pada lahan kebun campuran dan ubi kayu mengandung persentase partikel liat tertinggi dibandingkan partikel pasir dan debu. Fraksi tanah yang memiliki kemampuan besar dalam memegang air adalah fraksi liat. Liat adalah fraksi yang berpengaruh terhadap campuran fraksi lain, dengan sifat tanah yang didominasi oleh liat yaitu lengket, sulit menyerap air, dapat terpecah menjadi butiran yang halus saat keadaan kering. Fraksi debu biasanya berasal dari kandungan mineral feldspar dan mika yang cepat lapuk, pada saat pelapukan akan terjadi pembebasan sejumlah hara, sehingga tanah yang bertekstur debu lebih subur dibandingkan dengan yang bertekstur pasir, sedangkan fraksi pasir umumnya didominasi oleh mineral kuarsa yang sangat tahan terhadap pelapukan sehingga tanah yang terlalu banyak bertekstur pasir kurang baik untuk lahan pertanaman.

\section{C-Organik}

C-organik dalam tanah merupakan hasil dari pelapukan sisa sisa tanaman atau hewan yang bercampur dengan bahan mineral lain di dalam tanah pada lapisan atas tanah. C-organik penting untuk mikroorganisme tidak hanya sebagai unsur hara, tetapi juga sebagai pengkondisi sifat fisik tanah yang

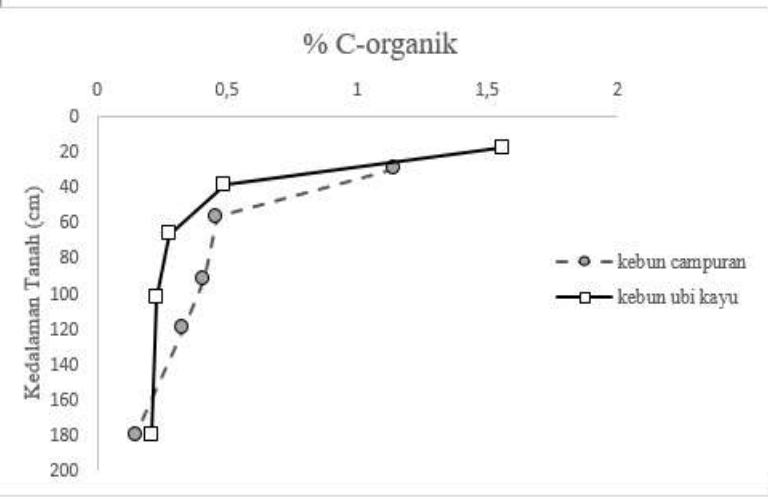

Gambar 2. Hubungan kedalaman profil tanah dan jenis lahan terhadap C-organik tanah.

mempengaruhi karakteristik agregat dan air tanah. Seringkali ada hubungan langsung antara persentase C-organik total dan karbon dari biomassa mikroba yang ditemukan dalam tanah pada zona iklim yang sama. C-organik juga berhubungan dengan aktivitas enzim tanah. Di perkebunan teh Gambung, C-organik tanah juga digunakan untuk menentukan dosis asam-asam organik dan apabila ditambahkan ke dalam tanah akan meningkatkan kandungan senyawa organik dalam tanah yang dicirikan dengan meningkatnya kadar Corganik tanah (Darliana, 2009).

Hasil penelitian menunjukkan bahwa lapisan permukaan tanah pada vegetasi kebun campuran memiliki kandungan $\mathrm{C}$ - organik lebih tinggi bila dibandingkan dengan lahan ubi kayu (Gambar 2). Hal ini disebabkan pada vegetasi kebun campuran terdiri dari beberapa tanaman yang masih alami terjaga lingkungannya yang menghasilkan serasah dan memiliki perkaran yang banyak sehingga serasah tertimbun pada lapisan top soil dan tanah pada kebun campuran belum dilakukan pengolahan tanah. Serasah yang dihasilkan terdekomposisi menjadi bahan organik yang mengakibatkan tanah berwarna cokelat hingga hitam. Faktor utama yang mempengaruhi kandungan bahan 
organik tanah adalah kedalaman tanah, iklim dan vegetasi.

\section{pH Tanah}

Berdasarkan hasil analisis di laboratorium tanah pada lahan kebun campuran memiliki nilai $\mathrm{pH}$ sebesar 4,60-4,77 sedangkan pada pertanaman ubi kayu memiliki nilai $\mathrm{pH}$ berkisar dari 4,28-4,68 pada lapisan profil tanah pertama hingga lapisan profil tanah kelima (Gambar 3). Nilai pH pada lapisan tanah lahan kebun campuran termasuk masam sedangkan pada lahan kebun ubi kayu termasuk kategori masam hingga sangat masam. Hal tersebut terjadi karena sebagian besar tanah di Lampung merupakan tanah Ultisol yang memiliki pH masam yakni di bawah 5,5 (Munir, 1996).

Meskipun secara umum kedua jenis lahan tersebut memiliki $\mathrm{pH}$ masam namun $\mathrm{pH}$ pada kebun campuran lebih tinggi dibandingkan dengan $\mathrm{pH}$ tanah pada kebun ubi kayu. Hal tersebut karena pada lahan pertanaman ubi kayu dilakukan olah tanah intensif dengan membajak seluruh permukaan tanah minimal sebanyak dua kali untuk menciptakan kondisi tanah yang gembur dan juga dilakukan pembersihan seluruh vegetasi yang terdapat di lahan sehingga permukaan

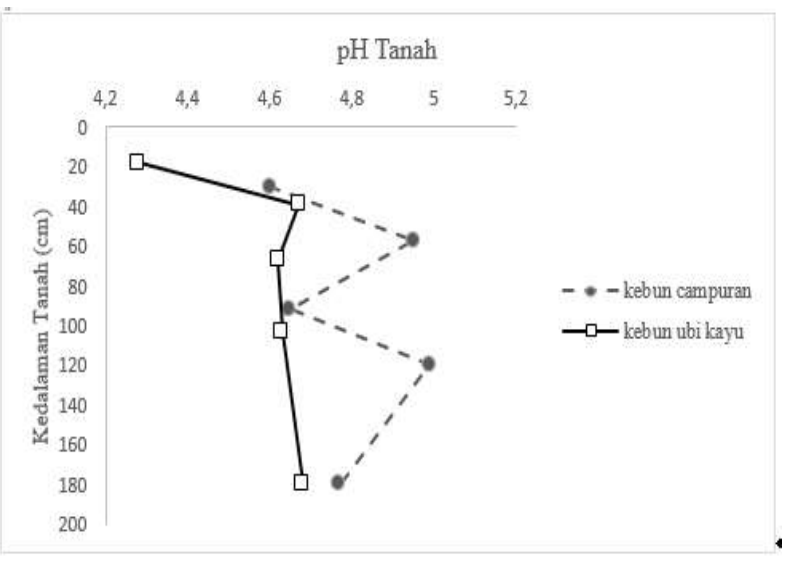

Gambar 3. Hubungan kedalaman profil tanah dan jenis lahan terhadap $\mathrm{pH}$ tanah. tanah rawan terjadi erosi. Selain itu tanaman ubi kayu memiliki luas kanopi yang rendah sehingga dianggap kurang mampu melindungi tanah dari pukulan air hujan dan menjadikan lahan ubi kayu peka terhadapa erosi. Ubi kayu juga dianggap sebagai tanaman yang menghasilkan bahan organik yang rendah dan mengangkut unsur hara lebih banyak dibandingkan tanaman lain. Erosi tanah dapat membawa kationkation basa di dalam tanah ke daerah yang lebih rendah sehingga lahan yang terkena erosi tersebut memiliki $\mathrm{pH}$ masam. Menurut Susilawati (2008), pH tanah yang rendah akan menyebabkan ketersediaan hara menurun dan perombakan bahan organik terhambat. Pada lahan kebun campuran tidak dilakukan pengolahan tanah karena tanaman yang terdapat pada lahan kebun campuran merupakan tanaman tahunan yang tumbuh secara alami. Kebun campuran memiliki kanopi daun yang luas karena terdiri dari tanaman tahunan sehingga tanah dapat terhindar dari resiko erosi.

\section{KTK Tanah}

Berdasarkan hasil analisis di laboratorium KTK tanah pada lahan kebun campuran dan pertanaman ubi kayu memiliki nilai KTK yang rendah berkisar dari 4,28-7,60 $\mathrm{cmol} \mathrm{kg}^{-1}$ (Gambar 4). Pada Gambar 4, terlihat bahwa semakin dalam lapisan profil tanah maka nilai KTK semakin tinggi terutama pada lahan kebun campuran. KTK tanah pada kedua jenis lahan termasuk rendah sebab nilai kapasitas tukar kation tanah pada umumnya berkisar antara $25-45 \mathrm{cmol} \mathrm{kg}^{-1}$ sampai dengan kedalaman 1 meter. KTK rendah berkisar 5$16 \mathrm{cmol} \mathrm{kg}^{-1}$ (Balai Penelitian Tanah, 2009). Pada kebanyakan tanah ditemukan bahwa pertukaran kation berubah dengan berubahnya $\mathrm{pH}$ tanah. Pada $\mathrm{pH}$ 


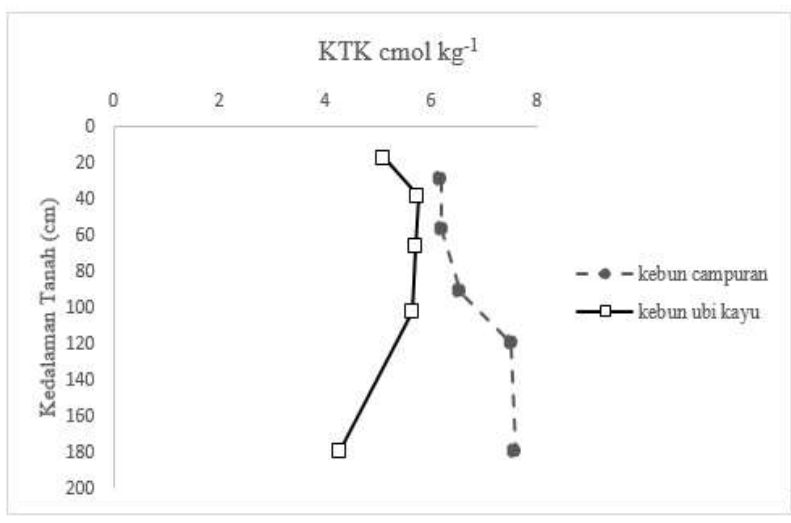

Gambar 4. Hubungan kedalaman profil tanah dan jenis lahan terhadap KTK tanah.

rendah, hanya muatan permanen liat, dan sebagian muatan koloid organik memegang ion yang dapat digantikan melalui pertukaran kation. Dengan demikian KTK relatif rendah (Hardjowigeno, 1993).

Hasil KTK yang diperoleh dalam penelitian ini sesuai dengan pendapat Foth (1998) yang menyatakan bahwa semakin tinggi tingkat kemasaman tanah maka semakin rendah kemampuan kapasitas tukar kation tanah atau nilai KTK tanah. Tanah Ultisol masam yang mendominasi kawasan lahan di Lampung memiliki nilai KTK rendah. Kemasaman tanah Ultisol terjadi karena tanah Ultisol adalah tanah yang terbentuk di daerah yang lembab. Tanah Ultisol bersifat masam dengan kejenuhan basa yang rendah, karena adanya pencucian kation basa. Suhu yang cukup tinggi dan pencucian yang lama mengakibatkan terjadinya pelapukan yang intensif pada mineral yang mudah lapuk.

\section{N - Total}

Pada Gambar 5 terlihat bahwa kandungan Ntotal di lapisan tanah pertama pada kebun ubi kayu lebih tinggi dari kebun campuran, namun memiliki kandungan $\mathrm{N}$-total yang relatif sama di lapisan profil kedua hingga kelima. Berdasarkan data tersebut dapat dilihat bahwa kedua kebun memiliki kandungan N-total rendah pada lapisan profil tanah pertama yakni $0,12 \%$ untuk kebun campuran dan $0,14 \%$ untuk kebun ubi kayu. Pada lapisan profil kedua sampai kelima baik pada kebun campuran dan kebun ubi kayu memiliki kandungan $\mathrm{N}$ total sangat rendah yakni $0,01-0,05 \%$.

Lebih tingginya kandungan $\mathrm{N}$-total pada lapisan permukaan (topsoil) disebabkan oleh adanya bahan organik yang memberikan sumbangan kedalam tanah. Hal ini mengidentifikasikan bahwa telah terjadi pelepasan hara dari proses dekomposisi bahan organik ke dalam tanah sebagai stimulan bertambahnya $\mathrm{N}$ tanah. Selanjutnya, penurunan kandungan nitrogen pada lapisan bawah (subsoil) dipengaruhi oleh penurunan jumlah bahan organik dan mikroorganisme tanah di lokasi tersebut. Karenadi dalam susunan jaringan bahan organikterkandung unsur nitrogen organik yang didekomposisi oleh mikroorganisme tanah menjadi nitrogen tersedia bagi tanaman (Izzudin, 2013).

\section{Kejenuhan Basa (KB)}

Hasil analisis kation basa dapat dipertukarkan memperlihatkan bahwa kejenuhan basa pada lapisan pertama lahan kebun campuran lebih tinggi

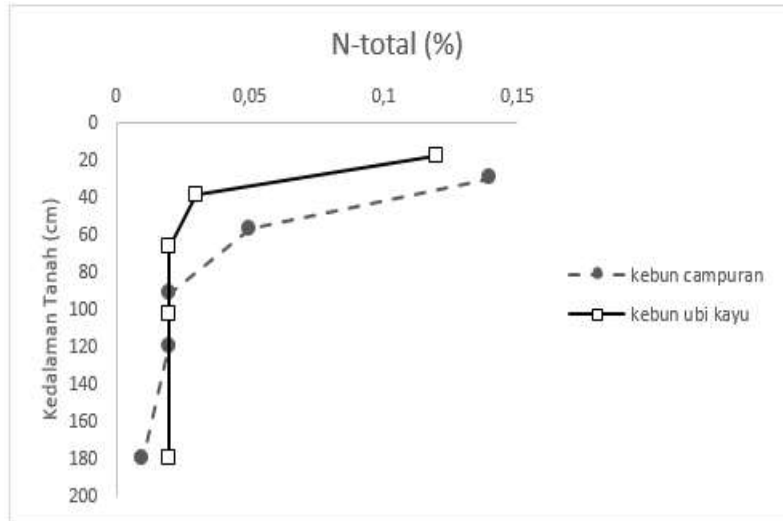

Gambar 5. Hubungan kedalaman profil tanah dan jenis lahan terhadap N-total 
dibandingkan dengan lahan pertanaman ubi kayu (Gambar 6). Lapisan pertama pada lahan kebun campuran memiliki kejenuhan basa sebesar 54,12\% yang tergolong sedang, sedangkan pada lahan pertanaman ubi kayu memiliki kejenuhan basa 49,60\% yang juga tergolong sedang. Pada lapisan kedua lahan kebun campuran dan lahan kebun ubi kayu mulai mengalami penurunan kejenuhan basa dan terus menurun hingga kedalaman lapisan kelima. Secara umum, kejenuhan basa pada lapisan kedua hingga kelima pada lahan ubi kayu lebih tinggi dibandingkan pada kebun campuran.

Lapisan pertama lahan kebun campuran memiliki kejenuhan basa sebesar 54,12\% yang artinya 54/100 atau lebih dari 1/2 kapasitas tukar kation ditempati oleh kationkation basa. Pada lapisan pertama lahan pertanaman ubi kayu memiliki persentase kejenuhan basa sebesar 49,60\% yang berarti hanya sekitar 49/100 atau kurang dari1/2 kapasitas tukar kation ditempati oleh kation-kation basa, sedangkan sebagian besar didominasi oleh $\mathrm{Al}^{3+}$ dan $\mathrm{H}^{+}$yang merupakan kation masam. Keadaan ini berbanding

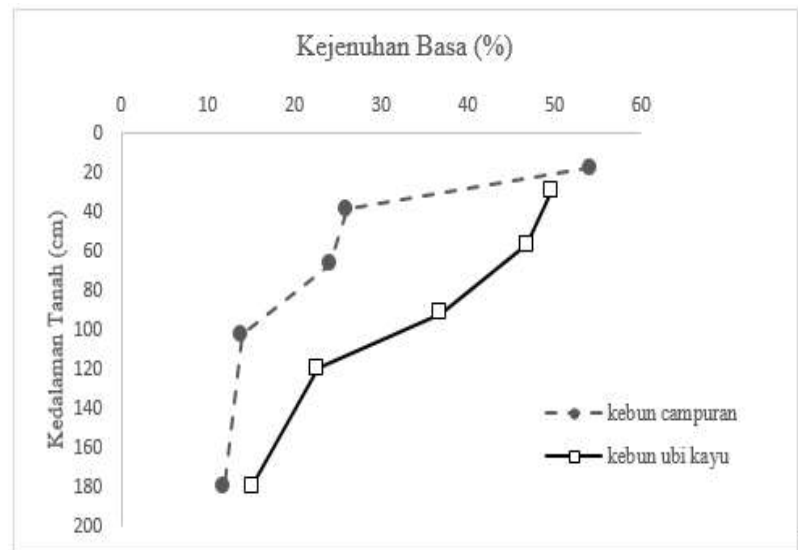

Gambar 6. Hubungan kedalaman profil tanah dan jenis lahan terhadap kejenuhan basa tanah. lurus dengan $\mathrm{pH}$ tanah yang menunjukkan bahwa $\mathrm{pH}$ tanah pada lapisan pertama lahan pertanaman ubi kayu lebih rendah dibandingkan kebun campuran.

\section{P-tersedia}

Berdasarkan hasil analisis laboratorium Ptersedia tanah pada lahan kebun campuran lebih tinggi dibandingkan kebun ubi kayu yaitu 1,52-2,73 ppm pada kebun campuran sedangkan pada kebun ubi kayu berkisar 1,53-1,74(Gambar 7). Semakin dalam lapisan profil tanah, nilai P-tersedia semakin rendah. Kandungan P-tersedia pada kedua lahan tersebut tergolong sangat rendah, yaitu $<4$ ppm (Balai Penelitian Tanah, 2009).

Rendahnya kandungan fosfor pada lahan pertanaman ubi kayu disebabkan salah satunya yaitu terangkut oleh tanaman. Total kehilangan P dari tanah karena diangkut tanaman semusim berkisar antara 5 $-6 \mathrm{~kg} \mathrm{ha}^{-1}$ (Rachman.A, 2013). Nilai $6 \mathrm{~kg} \mathrm{ha}^{-1}$ adalah sama dengan kurang lebih 0,4\% dari rata-rata kadar $\mathrm{P}$ dalam lapisan olah. Keadaan ini berbanding lurus dengan hasil uji laboratorium yang menunjukkan kandungan fosfor pada kebun ubi kayu lebih rendah dibandingkan kebun campuran.

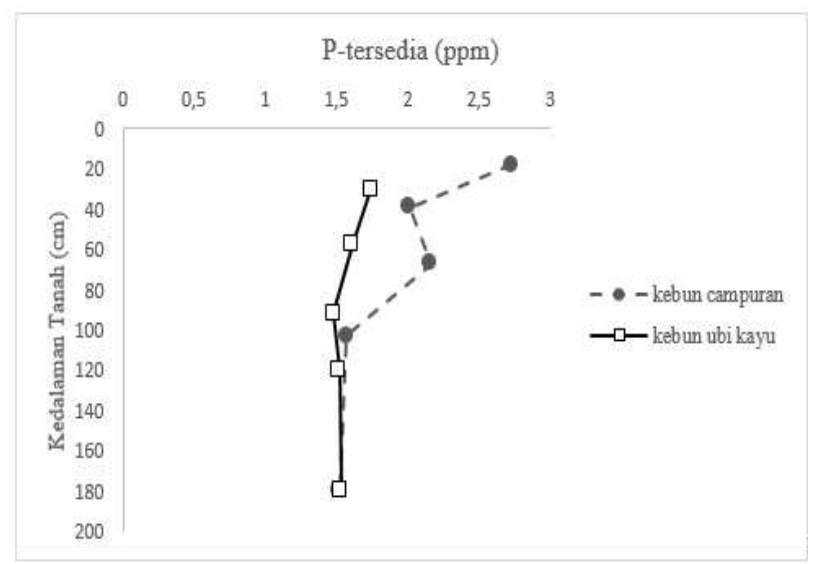

Gambar 7. Hubungan kedalaman profil tanah dan jenis lahan terhadap P-Tersedia. 


\section{KESIMPULAN}

Berdasarkan hasil penelitian yang telah dilakukan, maka dapat disimpulkan bahwa: Lahan kebun campuran memiliki lapisan permukaan tanah yang lebih tipis dan warna tanah yang lebih gelap dibandingkan lahan ubi kayu. Sementara pada lahan kebun campuran dan ubi kayu memiliki tekstur yang sama yaitu liat. Struktur tanah pada lapisan I pada kedua lahan tersebut berbeda, tetapi pada lapisan selanjutnya sama dan konsistensi tanah pada kedua lahan tersebut sama.

Nilai kandungan C-organik lahan kebun campuran lebih tinggi pada lapisan I, II dan V , sedangkan lapisan III dan IV lebih tinggi ubi kayu dibandingkan lahan kebun campuran. Nilai kandungan P-tersedia , pH dan KTK lapisan I sampai V pada lahan kebun campuran lebih tinggi dibandingkan lahan ubi kayu, sedangkan kandungan N-Total pada lapisan I lebih tinggi lahan ubi kayu. Kejenuhan Basa pada lapisan II, III, IV dan V profil tanah pada lahan ubi kayu lebih tinggi dibandingkan kebun campuran.

\section{DAFTAR PUSTAKA}

Balai Penelitian Tanah. 2004. Petunjuk Teknis Pengamatan Tanah. Badan Penelitian dan Pengembangan Pertanian Departemen Pertanian. Bogor. $140 \mathrm{hlm}$.

Cahyono, A. 1998. Bahan Assistensi dan Petunjuk Praktikum Ilmu Tanah Hutan. Fakultas Kehutanan UGM. Yogyakarta.
Chaniago, M., D.I. Roslim,dan Herman. 2014. Deskripsi Karakter Morfologi Ubi Kayu (Manihot esculenta Crantz) Juray dari Kabupaten Rokan Hulu. Jurnal Online Mahasiswa Fakultas Matematika dan Ilmu Pengetahuan Alam 1(2): 613- 618.

Darliana. 2005. Pengaruh jenis bokashi terhadap bobot isi, C-organik, dan KTK tanah, serta hasil daun teh pada Andosol asal Gambung. www.p4tkipa.org. Diakses tanggal 20September 2018.

Foth, H.D. 1998. Dasar-Dasar Ilmu Tanah. Edisi Ketujuh. Gajah Mada University Press. Yogyakarta. $782 \mathrm{hlm}$.

Hardjowigeno, S. 1992. Ilmu Tanah Edisi ketiga. Mediyatama Sarana Perkasa. Jakarta. $233 \mathrm{hlm}$

Izzudin, 2012.Perubahan Sifat Kimia dan Biologi Tanah Pasca Kegiatan Perambahan di Areal Hutan Pinus Reboisasi Kabupaten Humbang Hasunduta Provinsi Sumatera Utara. Skripsi. Fakultas Kehutanan. InstitutPertanian Bogor. Bogor.

Mahi, A.K. 2013. Survei Tanah, Evaluasi, dan Perencanaan Penggunaan Lahan. Lembaga Penelitian Universitas Lampung. Bandar Lampung. $218 \mathrm{hlm}$.

Munir, M. 1996. Tanah Ultisol; Tanah Ultisol di Indonesia. Pustaka Jaya. Jakarta.

Purwono, H. dan Purnamawati. 2007. Budidaya 8 Jenis Tanaman Pangan Unggul. Penebar Swadaya. Jakarta. $138 \mathrm{hlm}$. 